\title{
The role of biotechnology in ensuring the preservation of dry composite mixtures
}

\author{
Roza Timakova ${ }^{1, *}$, Alexander Akulich ${ }^{2}$, and Tatyana Samuylenko ${ }^{2}$ \\ ${ }^{1}$ USUE, 620144 Yekaterinburg, Russian Federation \\ ${ }^{2} \mathrm{UO}$ «Mogilev state University of food», 212027 Mogilev, Republic of Belarus
}

\begin{abstract}
Innovations in the agro-industrial sector are determined by the development of biotechnologies from the stage of growing raw materials to their processing and storage. In compliance with the phytosanitary requirements (including the use of radiation technologies) for grain, the issues of ensuring the preservation of dry composite mixtures are determined by the storage conditions and the use of bitechnological techniques for prolonging the shelf life when adding phytosources with antimicrobial action to them. The addition of nettle, Echinacea purpurea, sage and oak bark to mixtures consisting of $87.5 \%$ rye seed and extrusion flour and wheat flour of the first grade in an amount of $0.1 \%$ of the prescription composition made it possible to ensure compliance of such organoleptic indicators as color, whiteness and smell with the requirements of regulatory documents and to reduce microbiological contamination, as the most important factor in extending the shelf life, by 1.2-2.0 times up to 7-12 months. compared to the control samples. Echinacea purpurea has the greatest fungicidal effect, followed in descending order by sage, oak bark and nettle. The results obtained are of practical significance for the application of gentle biotechnologies in the production of dry composite mixtures.
\end{abstract}

\section{Introduction}

Innovative development of the agro-industrial sector of the economy of the Russian Federation and the Republic of Belarus in accordance with the Strategy of Economic Security of the Russian Federation for the period up to 2030, the Strategy of Development of the agroindustrial and Fisheries Complexes of the Russian Federation for the period up to 2030 and the Draft Program of Socio-economic Development of the Republic of Belarus for 20212025 is determined by the formation of markets for innovative biotechnologies in agriculture and in the food industry to achieve the technological quality of fresh and processed agricultural raw materials and their preservation during storage.

The stability of the technological properties of agricultural products as raw materials of plant and animal origin can be obtained in two ways: the first, as self-regulation of the technological system to ensure its sustainable development, as a result of selection from the available raw materials according to the technological parameters required for further processing, and the second, as self-development of the technological system due to the

${ }^{*}$ Corresponding author: trt64@mail.ru 
adaptation of the properties of raw materials, and the production of such raw materials in accordance with the requirements of processing and food technologies [1]. The first way is comparable to the development of biotechnologies in the food industry, the second is more focused on the development of agrobiotechnologies, including genetic bioengineering, breeding and organic technologies. At the same time, in order to ensure food security in accordance with the Sustainable Development Goals, the principle of preserving food resources, provided by the storage technologies used, is important. In 2015, the 2030 Agenda for Sustainable Development was adopted, one of the goals of which (SDG 12 - Responsible consumption and production) includes issues of reducing food losses [2], which requires the use of advanced storage technologies.

Grain is a strategically important product used in the food industry. The Russian Federation is the world's largest producer and exporter of wheat and barley. The Republic of Belarus exports mainly seeds and processed products: flour, pasta and bakery products, cereals.

After harvesting, some of the pests of grain crops can get together with the grain in the granaries. At this stage, the use of physical methods of processing, in particular radiation technologies, is considered a modern effective method of preserving grain, which allows us to meet the requirements of phytosanitary control and subsequent biosafety of processed products.

On the one hand, grain is a food resource with a long shelf life, on the other hand, according to the FAO, the main losses of grain occur after harvesting: rotting, damage by pests, fungi and microorganisms. The most common pests include the barn weevil, the grain grinder, and the Surinamese flour eater. To destroy them, certain doses and modes of radiation are used. At the moment, it is recommended to treat grain infected with pests with a dose of $200 \mathrm{G}$ [3]. According to [4], the advantage of using ionizing radiation for grain processing is the absence of fumigant residues in the processed grain, which allows for a high degree of sterility and microbiological purity.

When processing grain with ionizing radiation, losses from bacteria, fungi and insects can be reduced to $25-40 \%$. Even at low doses of radiation, the impact on pests will have an irreversible effect: the sterilization of individuals will be followed by a reduction in the population. If the impact is repeated over several years, the elimination of the species in the region is likely [5].

Studies of the effect of 60Co gamma radiation on infected wheat have shown that at doses from 1 to $25 \mathrm{kGy}$, the number of fungi decreases. When treated with a dose of $25 \mathrm{kGy}$, the complete decomposition of zearaleon, a product of the activity of the fungus Fusarium roseum, occurs. The quality of the grain does not change, as it happens when treated with fumigants or fertilizers [6].

When wheat flour is treated with gamma radiation at doses up to $1 \mathrm{kGy}$, the water absorption capacity and swelling capacity do not change [7]. According to [8], the treatment of flour with gamma radiation at doses of $0.2 \mathrm{kGy}, 0.5 \mathrm{kGy}, 2 \mathrm{kGy}$, and $5 \mathrm{kGy}$ allows the number of bacteria, mold and yeast to remain unchanged for 180 days, which provides an extension of the shelf life, but an increase in the dose leads to darkening of the color. The use of pulsed LED processing with wavelengths of 275, 365, 395 and $455 \mathrm{~nm}$ after 60 minutes of processing wheat flour leads to inactivation of Salmonella and a decrease in flour moisture, noted [9].

The storage of food products of plant origin not only does not lose its relevance, but also forms new tasks, which include the reduction of quality losses. This makes it possible to significantly increase competitiveness among similar food products during storage periods, and in some cases talk about the possibility of prolonging these periods [10]. 
Grain and its processed products are valuable sources of vegetable protein, starch, unsaturated fatty acids, minerals, B vitamins and enzymes involved in the physiological processes of the human body.

Dominant food products of plant origin in the structure of nutrition of any strata of the population are grain and flour products. They have always been given special attention during storage. This is due to a number of general and specific processes occurring during their storage, which serve as criteria for the expiration of storage periods.

Currently, one of the popular grain-and-flour products are dry composite mixtures [1115]. The advantages of using them include:

- the possibility of using it as a basis for the production of a wide range of food products of plant origin (bakery, pasta and flour confectionery, snack products, etc.).

- optimization of the structural composition of raw materials, depending on the functional focus of the developed range;

- organization of production processes in conditions of minimal technical equipment;

- reduction of the duration of the production cycle;

- convenience of cooking food in an incomplete technological cycle.

Technological innovations are largely based on the introduction of products of processing plant raw materials into ready-made multicomponent flour mixtures [16]. The consumer market is actively developing a segment of food products of mass consumption, including bakery products enriched with ingredients of plant origin to improve functional properties and increase nutritional value [17], for example, apple pomace [18].

An important direction for ensuring the preservation of food resources, in addition to the technology of processing raw materials to reduce populations of pests and microorganisms, is biotechnology aimed at activating antimicrobial properties and forming the antioxidant potential of the food product itself.

Thus, the preservation of dry composite mixtures for the production of bakery products significantly depends on the internal factors of production technology, among which the quantitative and qualitative ratio of nutrients plays a special role, the presence of which is due to a fairly wide list of recipe components included in dry composite mixtures, and the presence of substances with antimicrobial and a preservative effect. These substances can be contained both initially in dry composite mixtures, and introduced as an additional recipe component $[19,20]$. The most promising unconventional raw materials include phyto-raw materials. It has antimicrobial, fungicidal properties, increased antioxidant activity, slows down the course of oxidative processes, which is due to the presence in phyto-raw materials of polyphenolic compounds of various classes (flavonoids, anthocyanins, etc.). In addition, phyto-raw materials actively participate in the formation of the taste and aroma characteristics of food products, and also retain their properties for a long period of time, including after heat treatment [21-32]. Accordingly, the study of the influence of phyto-raw materials on the preservation of dry composite mixtures and the possibility of prolonging their shelf life is timely and relevant.

\section{Materials and Methods}

As objects of research, we used dry composite mixtures differing in the content of different types of phyto-raw materials: nettle (prototype 1), echinacea purpurea (prototype 2), sage (prototype 3) and oak bark (prototype 4), characterized by an increased content of polyphenols and antioxidant targeting. The choice of herbal raw materials is due to the following: nettle due to the content of flavonoids, essential oils, carotenoids (antioxidants); Echinacea purpurea - due to essential oils, flavonoids, tannins, resins, sage phytosterols - due to essential oils, flavonoids, phenolic compounds; oak bark - due to tannins, pectins, pentosans, catechins (antioxidants) and flavonoids, which have a bactericidal effect on 
microorganisms. In the control sample (sample 0), no phyto-raw materials were added. The choice of the amount of added phyto-raw materials is due to the compliance of such organoleptic indicators as appearance, color, whiteness and odor with the requirements of standards. The composition of the samples of dry composite mixtures is shown in Table 1.

Table 1. Formulation of dry composite mixtures

\begin{tabular}{|c|c|c|c|c|c|}
\hline \multirow{3}{*}{$\begin{array}{l}\text { Name of } \\
\text { raw materials components }\end{array}$} & \multicolumn{5}{|c|}{$\begin{array}{l}\text { The number of raw materials in the composition of dry } \\
\text { composite mixtures, } \%\end{array}$} \\
\hline & \multirow[t]{2}{*}{ Control samples } & \multicolumn{4}{|c|}{ Prototypes } \\
\hline & & 1 & 2 & 3 & 4 \\
\hline Seeded rye flour & 46,60 & 46,50 & 46,50 & 46,50 & 46,50 \\
\hline $\begin{array}{l}\text { Wheat flour of the first } \\
\text { grade }\end{array}$ & 36,50 & 36,50 & 36,50 & 36,50 & 36,50 \\
\hline Active dry baking yeast & 1,45 & 1,45 & 1,45 & 1,45 & 1,45 \\
\hline Iodized table salt & 1,45 & 1,45 & 1,45 & 1,45 & 1,45 \\
\hline Rye flour, extrusion & 4,50 & 4,50 & 4,50 & 4,50 & 4,50 \\
\hline Fermented dry rye malt & 4,50 & 4,50 & 4,50 & 4,50 & 4,50 \\
\hline Dry milk whey & 5,00 & 5,00 & 5,00 & 5,00 & 5,00 \\
\hline Nettle leaf powder & - & 0,10 & - & - & - \\
\hline $\begin{array}{l}\text { Echinacea purpurea herb } \\
\text { powder }\end{array}$ & - & - & 0,10 & - & - \\
\hline Oak Bark Powder & - & - & - & 0,10 & - \\
\hline Sage Leaf Powder & - & - & - & - & 0,10 \\
\hline
\end{tabular}

The number of mesophilic aerobic and facultative anaerobic microorganisms (NMAaFAM) was determined in accordance with standard methods of microbiological analysis on agar nutrient media. The research results were processed by the method of variation statistics. The study was carried out in five replicates.

\section{Results and Discussion}

One of the most important indicators by which one can judge about the expiration of the shelf life of grain and flour products, including dry composite mixtures, is the change in microbiological indicators, in particular, NMAaFAM. It is generally known that the content of microorganisms in flour usually depends on their initial content of microorganisms in the grain, the method of cleaning the grain, the type of flour and the conditions of its storage. The results of studies of microbiological quality indicators presented in Figure 1 show that on the day of preparation of dry composite mixtures NMAaFAM in a sample without phytoraw materials (control sample 0 ) and in samples with phyto-raw materials added (prototypes $1-4)$ are at the same level. 


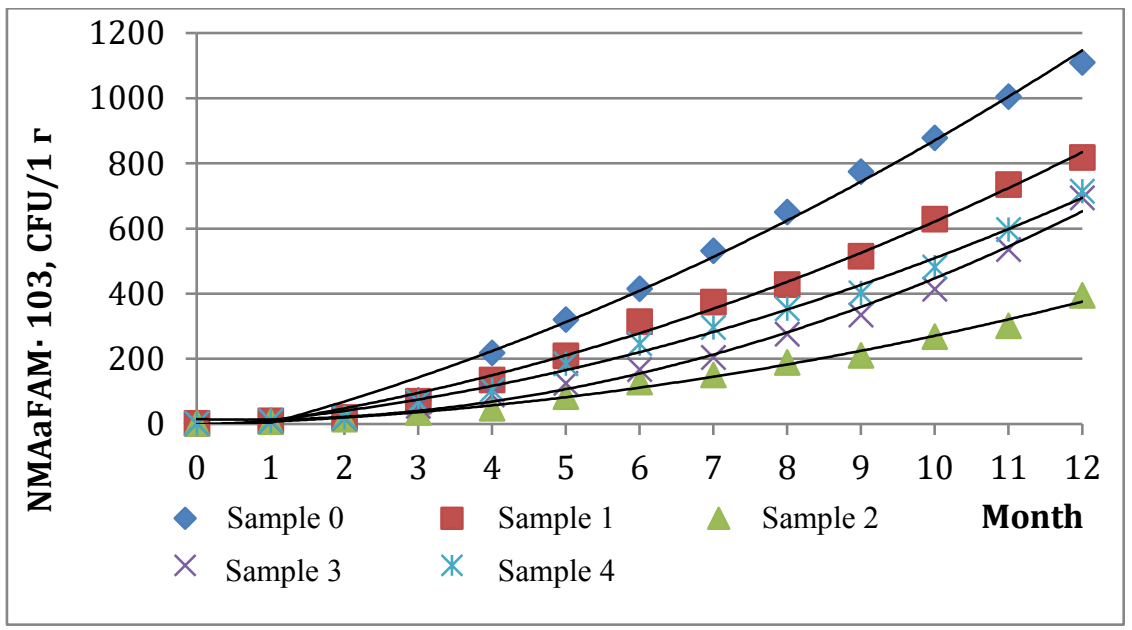

Fig. 1. Change in NMAaFAM during storage of dry composite mixtures without adding phyto-raw materials (control sample 0 ) and with the input of various types of phyto-raw materials (prototypes 1 , 2,3 and 4)

The results of studies of changes in NMAaFAM (CFU / $1 \mathrm{~g})$ during storage of dry composite mixtures with the input of various types of phyto-raw materials for 12 months show that NMAaFAM in dry composite mixtures increases during storage. The maximum growth of NMAaFAM is observed in sample 0 (without the input of phyto-raw materials), which is reflected by the largest coefficients in the equations (Table 2) and the greatest concavity of the trend line. The smallest increase in NMAaFAM is observed in sample 2 with the addition of Echinacea purpurea herb powder. Compared with sample 0 without adding phyto-raw materials NMAaFAM in experimental samples of dry composite mixtures with the addition of nettle leaf powder, Echinacea purpurea herb, oak bark, sage leaf was 1.4-2.8 times less after 12 months of storage. This testifies to the antimicrobial and fungicidal properties of herbal raw materials. It is known that storage of dry composite mixtures is provided for 6 months. NMAaFAM by the end of this period for sample 0 without phyto-raw material is $(415 \cdot 103) \mathrm{CFU} / 1 \mathrm{~g}$. In experimental samples $1-4$ with phyto-raw material added, NMAaFAM reaches this level in 7-12 months, depending on the type of phyto-raw material input into dry composite mixtures. The obtained research results are comparable with the research results [33].

The correlation of the change in NMAaFAM in the storage duration of dry composite mixtures are presented by polynomial equations of the second degree of the direct form with a high correlation coefficient equal to 0.99 (Table 2).

Table 2. Results of the correlation analysis

\begin{tabular}{|l|l|l|}
\hline Sample & Correlation & $\begin{array}{l}\text { Correlation } \\
\text { coefficient, } \mathrm{R}\end{array}$ \\
\hline 0 & $\mathrm{Y}=3,80 \cdot(\mathrm{X}) 2+54,58 \cdot \mathrm{X}-55,27$ & 0,99 \\
\hline 1 & $\mathrm{Y}=3,49 \cdot(\mathrm{X}) 2+29,76 \cdot \mathrm{X}-25,45$ & 0,99 \\
\hline 2 & $\mathrm{Y}=3,39 \cdot(\mathrm{X}) 2+17,94 \cdot \mathrm{X}-9,18$ & 0,99 \\
\hline 3 & $\mathrm{Y}=4,97 \cdot(\mathrm{X}) 2-6,53 \cdot \mathrm{X}+15,32$ & 0,99 \\
\hline 4 & $\mathrm{Y}=2,11 \cdot(\mathrm{X}) 2+6,06 \cdot \mathrm{X}-0,81$ & 0,99 \\
\hline
\end{tabular}


The results of the research allowed using correlation analysis to find out the correlation between the variables Y (quantitative value of NMAaFAM) and X (months), as well as to find an analytical expression of the intercorrelation. The change in the coefficients of the equations is due to the type of phyto-raw materials used in dry composite mixtures.

\section{Conclusions}

Based on the studies carried out, it was found that without preliminary physical treatment of prototypes of dry composite mixtures and only as a result of adding phyto-raw materials (nettle, Echinacea purpurea, sage and oak bark) in an amount of $0.1 \%$ of the recipe composition to dry composite mixtures reduction of microbiological contamination of test samples during storage up to 12 months compared to control samples. The greatest antimicrobial orientation was revealed in the experimental samples of mixtures with the addition of Echinacea purpurea, then, in descending order, there are experimental samples of dry composite mixtures with the addition of sage, oak bark and nettle. The practical application of the research carried out is determined by the repeatability of the results of modern biotechnological techniques.

\section{References}

1. V.A. Panfilov, Tekhn. i tekhnol. pishch. proizv., 2 (41), 73 (2016)

2. FAO, MFSR i VPP, 24 (2016)

3. A.A. Molin, Razvitie normativnogo regulirovaniya i populyarizaciya primenenij radiacionnyh tekhnologij $\mathrm{v}$ oblasti pishchevoj promyshlennosti, http://www.2012.atomexpo.ru/ (2012)

4. N.I. Sanzharova, S.A. Geras'kin, R.M. Aleksahin, G.V. Koz'min, N.N. Loj, N.N. Isamov (ml.), Vestn. Ross. s-h. nauki, 5, 21 (2013)

5. R.T. Timakova, Probl. i persp. razv. agroprom. proizv., monografiya, Penza: RIO PGAU, 58 (2020)

6. H.F. Mamedov, Immun., allerg., infekt., 1, 74 (2012)

7. B.R. Manupriva, Lathika, H.M. Somashekarappa et al., Rad. phys. and chem., 172, 108693 (2020)

8. F. Ansari, A. Homayouni, P. Mohsennezhad, A.M. Alivand, H. Pourjafar, Curr. nutr. \& Food sc., 16 (5), 757

9. S. Subedi, L. Du, A. Prasad, B. Yadav, M.S. Roopesh, Food and bioprod. proc., 121, 166 (2020)

10. O.A. Kornishko, E.V. Zhilyakov, E.V. Zhilyakov, Fund. issled., 5-3, 481 (2014)

11. T.I. Atamuratova, L.N. Hajdar-Zade, Univ.: tekhn. n., 7(64), 24 (2019)

12. T.A. Ershova, S.D. Bozhko, A.N. Chernyshova, I.O. Vahobova, Tekhnol. pishch. i pererab. prom. APK - prod. zdor. pit., 3(29), 32 (2019)

13. E.V. Nevskaya, I.A. Tyurina, O.E. Tyurina, M.T. SHulbaeva, M.N. Potapova, YA.S. Golovacheva, Tekhn. i tekhnol. pishch. proizv., 4(49), 531 (2019)

14. V.Yu. Ajrumyan, N.V. Sokol, E.A. Ol'hovatov, Tekhnol. i tovaroved. innov. pishch. prod., 5(64), 40 (2020)

15. G.N. Pankratov, E.P. Meleshkina, I.S. Vitol, S.N. Kolomiec, I.A. Kechkin, Pishch. prom., 2, 55 (2021) 
16. O. I. Stabrovskaya, A. C. Romanov, O. G. Korotkova, Tekhn. i tekhnol. pishch. proizv., 2, 30 (2009)

17. N.V. Naumenko, I.Yu. Potoroko, I.V. Kalinina, A.V. Malinin, A.V. Caturov, Vestn. Voronezh. gos. un. inzh. tekhnol., 81(2), 108 (2019)

18. R.T. Timakova, NIU ITMO, 2(44), 22 (2020)

19. T. Samuylenko, T. Gurinova, V. Tomashov, Conference with International Participation, LXVI (1), 49 (2019)

20. T. Samuylenko, J. of Food Sc. and Eng., 9, 355 (2019)

21. G. N. Dubcova, R. N. Negmatulloeva, Hran. i pererab. sel'hozsyr., 4, 46 (2011)

22. A. YA. YAshin, N.I. CHernousova, Kond. i hlebopek. proizv., 7, 36 (2012)

23. V. E. Drevin, T.A. Shipaeva, V.I. Komarova, Hran. i pererab. sel'hozsyr., 12, 41 (2013)

24. T. B. Cyganova, N. G. Semenkina, T. V. Bykovchenko, Hlebopech. Ross., 6, 27 (2013)

25. A. V. Georgieva, Pishch. prom.: nauka i tekhnol., 4, 39 (2014)

26. G. A. Presnova, N. A. Tyurina, Kond. i hlebopek. proizv., 3-4, 48 (2015)

27. N.A. Sidel'nikova, T.A. Shmakova, Usp. sovr. nauki i obraz., 9(12), 91 (2016)

28. S.L. Masanskij, O.V. Krukovich. Spec. nap. s izm. okisl.--vosst. potenc., 230 (2017)

29. T.N. Tertychnaya, M.V. Anosova, S.V. Kalashnikova, K.V. Krasnikova, Tekhnol. i tovaroved. s.-h. prod., 2(13), 94 (2019)

30. S.A. Konovalov, O.A. Konovalova, O.N. YAshchenko, T.V. Gammershmidt, Vseross. (nac.) nauch.-prakt. konf., 539 (2019)

31. I.A. Bakin, A.S. Mustafina, K.A. Dudka, Mezhdunar. nauch.-prakt. konf., 236 (2019)

32. A.A. Kurochkin, N.E. Kruchinina, Innovac. tekhn. i tekhnol., 4(25), 19 (2020)

33. N.A. Emelina, I.A. Tyurina, E.V. Nevskaya, Nauch.-prakt. mol. konf., 319 (2020) 